Journal of Environmental Science and Public Health

doi: 10.26502/JESPH.008

Volume 1, Issue 2

Research Article

\title{
Anthropogenic Activities and the Quality of Aquatic Habitat with Reference to Heptachlor in Ethiope River Basin
}

Ikpesu $\mathrm{TO}^{1^{*}}$, Erewa $\mathrm{O}^{2}$ and Anyiam $\mathrm{IV}^{3}$

${ }^{1}$ Department of Biology, Federal University Otuoke, Nigeria

${ }^{2}$ Department of Animal and Environmental Biology, University of Benin, Nigeria

${ }^{3}$ Department of Microbiology, Federal University Otuoke, Nigeria

*Corresponding Author: Ikpesu TO, Department of Biology, Federal University Otuoke, Nigeria, Tel: +2348032312141; E-mail address: tomohwofasa@yahoo.com

Received: 28 June 2017; Accepted: 21 July 2017; Published: 02 August 2017

\begin{abstract}
The influences of man on the quality of aquatic habitat is indispensable, hence the distribution of heptachlor, one of the most sought pesticide in the nascent fragile Niger- Delta environment in the water, bottom sediment and Tilapia mariae in Ethiope River Basin was investigated. Samples were collected monthly from three stations, Amukpe, Igun watershed and Owah-Abe, all along the River during the dry (January-April) and wet seasons (May-August).These stations were chosen because of their close proximity to where the pesticide is regularly use except the control station. The concentration of the pesticide was analyzed using CECIL 1010 model of high performance liquid chromatography. The results revealed a higher concentration of the pesticide in surface water during the dry season, than the wet season while the reverse was the case for the bottom sediment and T. mariae which had higher concentrations during the rainy season. Spatial variations showed that the downstream stations had statistically higher concentrations in all matrices at $\mathrm{p}<0.05$. The observed concentrations of heptachlor were above the permissible limits set by Nigeria National Environment Standards and Regulation Enforcement Agency for aquatic water bodies $(0.3 \mu \mathrm{g} / \mathrm{gdw})$. Though, fishes and the likes may live freely in water contaminated with heptachlor, for a very long time with no health effects. However, pesticides can easily biomagnified along the trophic level, and the risk to aquatic species become greater when repeated applications occur, resulting in continual exposure to peak concentrations.
\end{abstract}

Keywords: Heptachlor; Surface water; Sediment; T. mariae; Ethiope River 


\section{Introduction}

Man in an attempt to improve the quality of life, has greatly disturb the balance of nature. Pollution of aquatic environment could come from dredging activities, sanitary sewers and construction activities [1]. Most of water pollution occurs due to leaching and mixing of chemicals from the agriculture practices [2]. Pesticides are toxic substances, and are not a naturally occurring substance in aquatic ecosystems. They are introduced directly or indirectly by man. One major group of pesticide that is often use in the developing world is the organochlorine pesticides. Organochlorine pesticides (OCP) stay in the environment for a very long time, and it has been a source of concern because of their chronic toxicity to living things through water and food intake. Many OC pesticides including their metabolites have the potentials of disrupting endocrine, cause cancer, inhibiting and inducing oxidative stress enzymes [3].

The broad-spectrum of pesticide improvement is from highly toxic and importunate pesticides like heptachlor, to easily degradable pesticides that are less lethal to non-target organisms. Some countries have banned many of the older pesticides due to their toxicity human and/or their consequences on ecosystems, in favour of more modern pesticide formulations. In countries, especially within the Africa continent, the old pesticides are readily available because they are more effective and then most of the modern pesticides for example, heptachlor has been in use for the control termites without failure. Besides, the developing countries uphold the believed that the modern pesticides are very expensive and are beyond the reach of a common man. The impasse of price/efficiency and environmental responses, especially long range effects through air transport and access to contemporary pesticide production at low cost remains a contentious global issue.

Heptachlor is highly toxic to man, can be absorbed through the skin, lungs and gastrointestinal tract. It could be responsible for hyperexcitation of the nervous system and cause internal organ damage, especially the liver [4]. The EPA has established a lifetime health advisory level for heptachlor of $17.5 \mathrm{ug} / \mathrm{l}$ and for heptachlor epoxide of 0.4 ug/l. The U.S. FDA maximum value of heptachlor on food crops is $0.01 \mathrm{ug} / \mathrm{l}$, while $0.3 \mathrm{ug} / 1$ was recommended on on edible seafood [5]. Thus, it can be deduced that a person may take water containing heptachlor or heptachlor epoxide at or below these levels daily for a very long period with no health effects. The limit of heptachlor and its metabolite for drinking water recommended by United State regulatory body are: heptachlor, $0.0104 \mathrm{ppb}$; and heptachlor epoxide, $0.0006 \mathrm{ppb}[6]$.

Fish are used extensively for environmental monitoring [5] because they uptake contaminants directly from water and diet. Generally, fish can easily metabolize contaminants such as organochlorine; therefore, concentrations level in fish will reflect the state of contamination in surrounding environments [7]. Heptachlor is toxic to aquatic organisms (especially snails, worms, crayfish, etc), and the pesticide and its metabolite have been implicated in accumulation in aquatic organisms [6]. Caution should therefore be taken to ensure that these products do not unnecessarily find its way to aquatic system. If the pesticide enters the aquatic system, nontarget animals will be affected, invariably pose a hazard to the lives of human, domestic animals and non-target plants. Hence, the objectives of this study are to evaluate the levels of heptachlor residues in the water, bottom sediments and $T$. 
mariae from the Ethiope River basin and also the spatial-temporal distribution of the heptachlor residues in this River.

\section{Materials and Methods}

\subsection{Investigated river}

The Ethiope River is located in the North Central part of Delta State, Nigeria between (Latitudes $05^{\circ} 52.390^{\prime}-05^{\circ}$ 51. 592' $\mathrm{N}$ and Longitude $\left.006^{\circ} 10.675^{\prime}-005^{\circ} 43.863^{\prime} \mathrm{E}\right)$. The River meets several socio-economic needs of the towns and villages within the catchment of the River. Three sampling stations were established at Amukpe, Igun watershed and Owah-Abe (Figure 1). The ecological zone is within the equatorial county, which experience two climatic systems: the rainy season, which commences in April, and ends in October and the dry season (November to March). With the incidence of climate change, the seasons fluctuate from year to year. Mean annual rainfall in the region is $2800 \mathrm{~mm}$ with temperatures varying between $23^{\circ} \mathrm{C}$ and $37^{\circ} \mathrm{C}$ in the afternoon and dropping to between $18^{\circ} \mathrm{C}$ and $22^{\circ} \mathrm{C}$ at night.

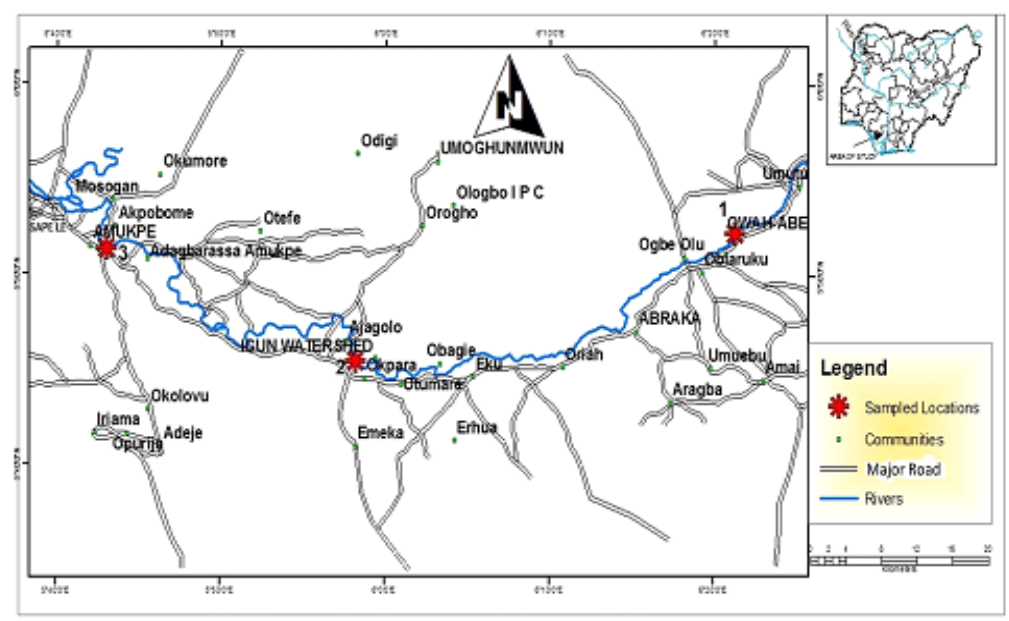

Figure 1: May of study area showing the sampled location.

\subsection{Sampling strategy}

Three sampling points were selected and visited on monthly basis to collect surface water, sediment and T. mariae for heptachlor analysis. Wet season sampling was carried out between April to October, while dry sampling was done between November and March. Analysis of physicochemical parameters of surface water was also carried out.

\subsection{Samples collection}

One Liter of water samples were collected within each station along the River by grab method. Four grab samples were taken across the width of the river and pulled together to form a composite sample. Water sample was stored in a sterilized cleaned glass bottle and acidified with $\mathrm{HNO}_{3}$ to $\mathrm{pH} 2$ to avoid change of the organic matter contents and kept in a refrigerator. The upper $2 \mathrm{~cm}$ of the bed sediment at each site was taken from where fine-texture substrates accumulated with a sterilized cleaned Ekman grab sampler and wrapped in aluminum foil. The samples (sediments) were dried at room temperature, sieved using $2 \mathrm{~mm}$ mesh size, then stored in black polythene bags ready for analysis. 
T. mariae were caught using drag net method. Fish caught from each sampling station were kept in plastic bag, and properly labeled. They (the fish) were immediately placed on ice during transport $(<6 \mathrm{~h})$ to reduce microbial activities and then stored at $-20^{\circ} \mathrm{C}$ in the laboratory until analysis.

\section{Chemical Analysis}

\subsection{Extraction of heptachlor from water sample}

Extraction of heptachlor from water was conducted using EPA 3510 method [8]. One liter of water was extracted using $50 \mathrm{ml}$ of dichloromethane in a separating funnel were shaken vigorously for about 5 minutes. The sample was allowed to settle for 30 minutes to ensure separation of the phases. After separation, the organic layer was filtered into a $250 \mathrm{ml}$ conical flask through anhydrous sodium sulphate $\left(\mathrm{Na}_{2} \mathrm{SO}_{4}\right)$ that has been prewashed with dichloromethane.

The extractions were repeated twice using a $50 \mathrm{ml}$ portion of dichloromethane and later combined. The combined organic extracts were concentrated using a rotary evaporator at $45^{\circ} \mathrm{C}$ and low pressure. $5 \mathrm{ml}$ of $\mathrm{n}$-hexane was added to the extract in dichloromethane to exchange the solvent. The extracts were further concentrated to 1-2 $\mathrm{ml}$ using a rotary evaporator at $45^{\circ} \mathrm{C}$ until no further dichloromethane remained in the extract and eluted with $\mathrm{N}$-hexane.

\subsection{Extraction of heptachlor from sediment}

Extraction of heptachlor from sediments was conducted using EPA 3510 method [9] with slight modification. Wet sediment samples were dried until constant dry weight was obtained. Samples were then homogenized, and passed through a no 32 mesh sieve. $20 \mathrm{~g}$ of the sample and $20 \mathrm{~g}$ of anhydrous $\mathrm{Na}_{2} \mathrm{SO}_{4}$ was added. $50 \mathrm{ml}$ mixture of acetone and $\mathrm{n}$-hexane $(1: 1 \mathrm{v} / \mathrm{v})$ were then mixed with the sample in a $100 \mathrm{ml}$ volumetric flask. This was followed by sonication in a high frequency ultra-sonic bath for $10-15$ minutes at about $60^{\circ} \mathrm{C}$. The extract was then decanted into a round bottom flask.

The extraction process was repeated with additional $50 \mathrm{ml}$ (acetone and $\mathrm{n}$-hexane), sonicated and allowed to settle and decant into the same round bottom flask. The extracts was concentrated using a rotary evaporator to 1-2 ml. The extract was re-dissolved in $5 \mathrm{ml} \mathrm{n}$-hexane and later concentrated to $2 \mathrm{ml}$ in a rotary evaporator at $40^{\circ} \mathrm{C}$ and eluted with N-hexane.

\subsection{Extraction of heptachlor from fish samples}

The samples were weighed, oven-dried, ground, homogenized and stored in clean plastic bottles with tight seals. One gram of dried fish tissue was weighed into a clean extraction bottle containing $25 \mathrm{~g}$ of $\mathrm{Na}_{2} \mathrm{SO}_{4}$. Acetone: $\mathrm{n}$ hexane $(1: 1 \mathrm{v} / \mathrm{v})$ of $40 \mathrm{ml}$ was added and the mixtures were sonicated for 15 minutes. The extracts were filtered into a round bottom flask.

The extraction process was repeated with additional $40 \mathrm{ml}$ (acetone and $\mathrm{n}$-hexane), sonicated and allowed to settle and filtered into the same round bottom flask. The extract was concentrated to $2 \mathrm{ml}$ using a rotary evaporator. The 
extract was re-dissolved in $5 \mathrm{ml} \mathrm{n}$-hexane and later concentrated to $2 \mathrm{ml}$ in a rotary evaporator at $40^{\circ} \mathrm{C}$ and eluted using n-hexane [10]

\subsection{Extract cleanup}

All samples were cleaned up by Florisil column before analysis by High performance liquid chromatography. Each of the raw extracts was dissolved in $10 \mathrm{ml}$ hexane and passed through pre-conditioned octadecyl C-18 columns at a rate of $2 \mathrm{ml} \mathrm{minG1}$ to clean up. Activated $\mathrm{Cu}$ powder was added in a stepwise manner and in very small amounts to the extract to remove any sulphur that might be present; the $\mathrm{Cu}$ powder will turn black as a result of oxidation if sulphur is present; the addition continued until this reaction seized. About $3 \mathrm{~g}$ of activated florisil was weighed and poured into a glass column which has been plugged with glass wool and packed very well followed by $1.5 \mathrm{~g}$ layer of anhydrous sodium sulphate.

The column was filled with $5 \mathrm{ml}$ portions of hexane and the stopcock was opened to let hexane run out while taping the column to settle the florisil until hexane just reached the top of the sodium sulfate. The sample extract was then transferred onto the florisil column, and eluted with $10 \mathrm{ml}$ portions of hexane using Pasteur pipette. The eluate was collected into a round bottom flask and evaporated to dryness using a rotary evaporator and dissolved in $1 \mathrm{ml}$ of ethyl acetate for HPLC analysis

3.4.1 HPLC mobile phase preparation: The solvent of the mobile phase of the HPLC is methanol and water (1:1). This was prepared by measuring $250 \mathrm{ml}$ of HPLC grade methanol into a $500 \mathrm{ml}$ flask and made up with $250 \mathrm{ml}$ of distilled water

3.4.2 Activation of the HPLC system: The HPLC model CECIL 1010 was switched on. The wavelength of the system was determined by using UV visible equipment. Little quantity of the stock solution was diluted with methanol and its wavelength determined by scanning. A pack of $202 \mathrm{~nm}$ was reached. The system wavelength was then set at $202 \mathrm{~nm}$ and the sensitivity of the $0.05 \mathrm{~nm}$ of the uv detector component set. The flow rate was set at $1 \mathrm{ml} / \mathrm{min}$. the purging of the system commenced by allowing the system to run for some time. This was done to remove air from the system and also to make the colon charged. The purging was carried out through a washing solution of $30 \%$ methanol; $70 \%$ water.

3.4.3 Determination of heptachlor concentration: The internal standard for the heptachlor was injected manually through a Rheodyne injector. HPLC working conditions were, Binary gradient, Eluent solvent (Acetonitrile: water; 70:30) and flow rate $0.8 \mathrm{~mL} \mathrm{~min}^{-1}$ and injection volume (loop size) $100 \mu \mathrm{L}$ and the wavelength of the UV/visible detector was fixed at $202 \mathrm{~nm}$ for the residual analysis of the pesticide. The series of concentrations starting from $100 \mathrm{ppm}$ to $0.025 \mathrm{ppm}$ were loaded and injected and their chromatograph printed out. The resulting peak areas were then used to plot a graph against concentration to determine the linearity of heptachlor standard chromatographs. The retentions time for the pesticide standard was 4.7 and the concentrations determined and recorded. 
3.4.4 Data Analysis: The data were analysed separately for each station using Description Statistics (means, range, standard deviation, standard error). Statistical differences between the seasons were analyzed using Student's t-test, while the differences between the polluted and reference stations were analyzed using one-way analysis of variance with confidence range of $\mathrm{p}<0.05$ with SPSS (16.0 version), SPSS Inc, USA. Multiple bar graphs were used for pictorial representation.

\section{Results}

The physicochemical parameters of the River is in conformity with water quality standard range recommended for domestic water by the National Academy of Engineering guidelines for the protection of aquatic life. The results of seasonal and spatial variations in concentrations of Heptachlor residues in surface water, bottom sediments and $T$. marie from the Ethiope River are given in Tables 1, 2 and 3 with further illustrations in Figures 2, 3 and 4.

\subsection{Heptachlor residues in surface water}

The mean concentrations of Heptachlor residues in the water after eight months of sampling in the three selected stations along the Ethiope River were $0.37 \mu \mathrm{g} \mathrm{L}^{-1}$, Amukpe, $0.08 \mu \mathrm{g} \mathrm{L}^{-1}$, Igun water shed, and $0.01 \mu \mathrm{g} \mathrm{L}^{-1}$ at Owah Abe (Figure 1). The respective mean values for dry and wet seasons were $0.74 \mu \mathrm{g} \mathrm{L} \mathrm{L}^{-1}$ and $0.01 \mu \mathrm{L}^{-1}$ at Amukpe, 0.16 $\mu \mathrm{g} \mathrm{L}^{-1}$ and $0.00 \mu \mathrm{g} \mathrm{L}^{-1}$ at Igun water shed, 0.01 and $0.00 \mu \mathrm{g} \mathrm{L} \mathrm{L}^{-1}$ at Owah-Abe (Table 1). Limit of detection is $0.01 \mu \mathrm{g}$ $\mathrm{L}^{-1}$.

\begin{tabular}{|l|l|l|l|l|l|l|}
\hline \multirow{3}{*}{ Stations } & \multicolumn{5}{|c|}{ Surface Water } \\
\cline { 2 - 7 } & \multicolumn{3}{|c|}{ Dry Season } & \multicolumn{3}{c|}{ Wet Season } \\
\cline { 2 - 7 } & Mean \pm SD & SE & Range & Mean \pm SD & SE & Range \\
\hline Amukpe & $0.74 \pm 0.19$ & 0.10 & $0.54-1.00$ & $0.01 \pm 0.02$ & 0.01 & $0.00-0.03$ \\
\hline Igun watershed & $0.16 \pm 0.25$ & 0.15 & $0.01-0.60$ & ND & - & ND \\
\hline Owah-Abe & $0.01 \pm 0.05$ & 0.00 & $0.01-0.02$ & ND & - & ND \\
\hline
\end{tabular}

Table 1: Levels of Heptachlor residues during the dry and wet seasons in surface water, at three sites along the Ethiope River, sampled monthly from January - April (dry), May - August (wet). The means are based on monthly measurements, $\mathrm{ND}=$ Not detectable.

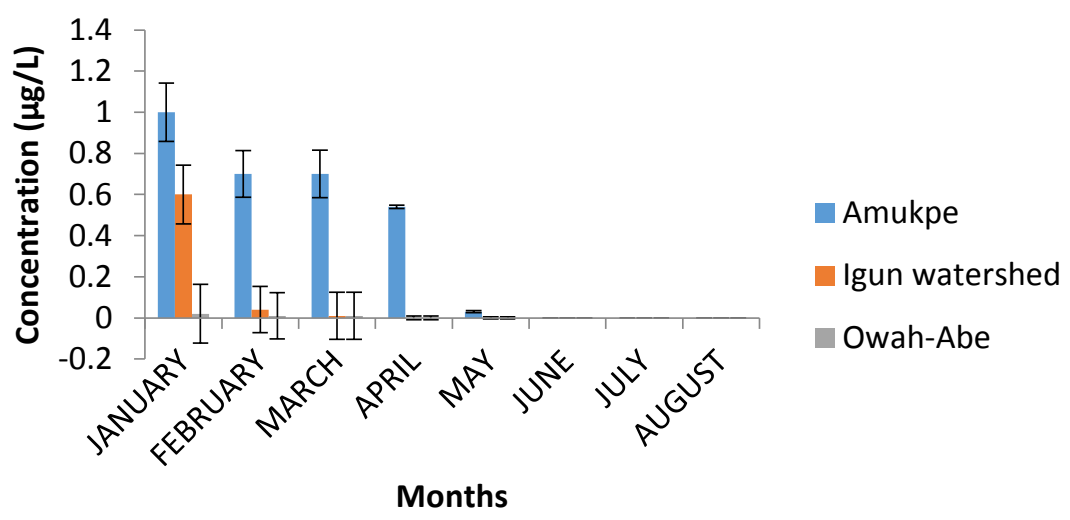

Figure 2: Concentration of Heptachlor in surface water of the Ethiope River, Niger Delta, Nigeria. Data are presented as monthly concentrations \pm standard error. 


\subsection{Heptachlor residues in sediment}

Figure 2 shows the concentrations of Heptachlor residues in the sediment samples from the Ethiope River. The highest concentration of $8.50 \mu \mathrm{gdw}^{-1}$ was recorded at Amukpe in the month of August. $3.78 \mu \mathrm{g} \mathrm{gdw}^{-1}$ was observed at Igun watershed and $1.10 \mu \mathrm{g} \mathrm{gdw}^{-1}$ at Owah-Abe also in the month of August. The respective means for dry and wet season were $0.74 \mu \mathrm{g} \mathrm{gdw}^{-1}$ and $6.15 \mu \mathrm{g} \mathrm{gdw}^{-1}$, Amukpe, $0.27 \mu \mathrm{gdw}^{-1}$, and $2.51 \mu \mathrm{g} \mathrm{gdw}^{-1}$, Igun water shed, and $0.09 \mu \mathrm{gdw}^{-1}$ and $0.73 \mu \mathrm{gdw}^{-1}$ at Owah Abe. Limit of detection is $0.01 \mu \mathrm{gdw}^{-1}$.

\begin{tabular}{|l|l|l|l|l|l|l|}
\hline \multirow{2}{*}{ Stations } & \multicolumn{6}{|c|}{ Sediment } \\
\cline { 2 - 7 } & \multicolumn{3}{|c|}{ Dry Season } & \multicolumn{3}{c|}{ Wet Season } \\
\cline { 2 - 7 } & Mean \pm SD & SE & Range & Mean \pm SD & SE & Range \\
\hline Amukpe & $0.74 \pm 0.72$ & 0.36 & $0.20-1.80$ & $6.15 \pm 2.07$ & 1.03 & $4.00-8.50$ \\
\hline Igun watershed & $0.28 \pm 0.15$ & 0.07 & $0.10-0.46$ & $2.51 \pm 1.33$ & 0.67 & $0.65-3.78$ \\
\hline Owah-Abe & $0.09 \pm 0.04$ & 0.02 & $0.04-0.12$ & $0.73 \pm 0.37$ & 0.18 & $0.24-1.10$ \\
\hline
\end{tabular}

Table 2: Levels of Heptachlor residues in sediment during the dry and wet seasons at three sites along the Ethiope

River, sampled monthly from January - April (dry), May - August (wet). The means are based on monthly observations.

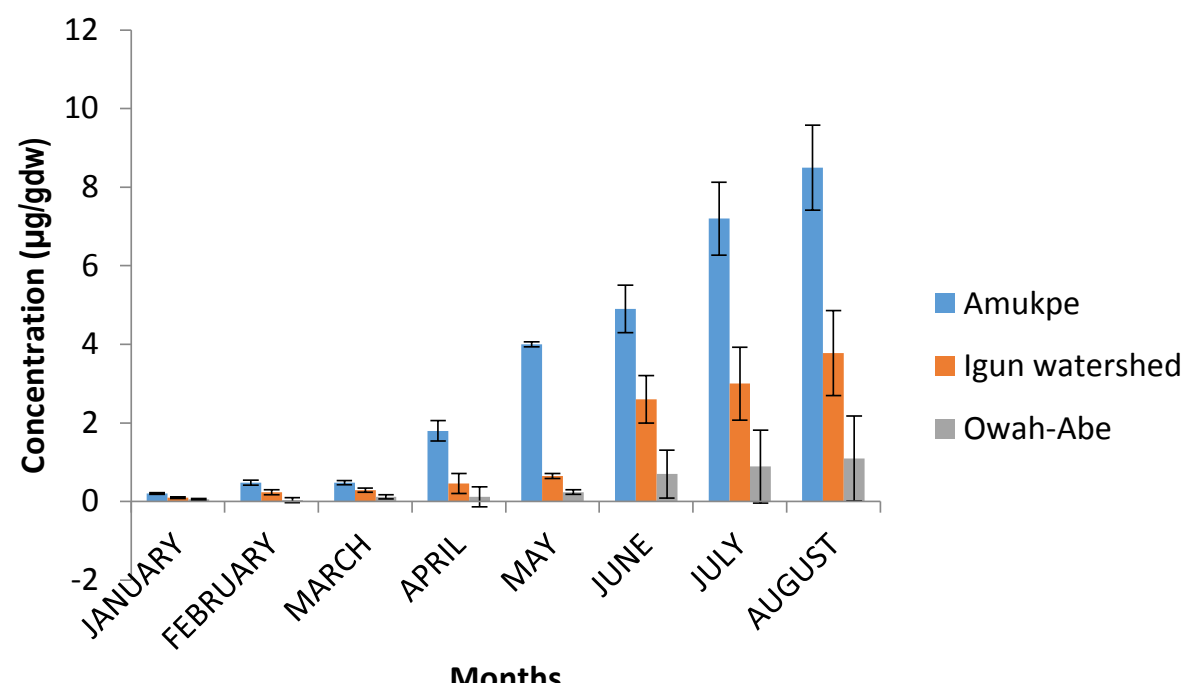

Figure 3: Heptachlor concentration in sediment of the Ethiope River, Niger Delta, Nigeria. Data are presented as monthly concentrations \pm standard error.

\subsection{Heptachlor concentrations in fish}

Figure 3 shows the concentrations of Heptachlor residues in the fish samples from the Ethiope River. Comparing the three sampling sites, the highest concentrations of $9.00 \mu \mathrm{g} \mathrm{gdw}^{-1}$ was recorded at Amukpe in the month of August, followed by $4.00 \mu \mathrm{g} \mathrm{gdw}^{-1}$ at Igun water shed and $2.90 \mu \mathrm{g} \mathrm{gdw}^{-1}$ at Owah Abe in the same month. The respective 
means for dry and wet season were $1.58 \mu \mathrm{gdw}^{-1}$ and $7.22 \mu \mathrm{gdw}^{-1}$, Amukpe, $0.84 \mu \mathrm{g} \mathrm{gdw}^{-1}$ and $2.34 \mu \mathrm{gdw}^{-1}$, Igun water shed, and $0.92 \mu \mathrm{gdw}^{-1}$ and $1.89 \mu \mathrm{g} \mathrm{gdw}^{-1}$ at Owah Abe. Limit of detection is $0.01 \mu \mathrm{g} \mathrm{gdw}^{-1}$.

\begin{tabular}{|l|l|l|l|l|l|l|}
\hline \multicolumn{1}{|c|}{ Stations } & \multicolumn{7}{|l|}{ T. mariae } \\
\hline & \multicolumn{2}{|l|}{ Dry Season } & \multicolumn{2}{l|}{ Wet Season } \\
\hline & Mean \pm SD & SE & Range & Mean \pm SD & SE & Range \\
\hline Amukpe & $1.58 \pm 1.05$ & 0.52 & $0.52-3.00$ & $7.22 \pm 2.11$ & 1.05 & $4.20-9.00$ \\
\hline Igun watershed & $0.84 \pm 0.14$ & 0.07 & $0.64-0.96$ & $2.34 \pm 1.11$ & 0.56 & $1.70-4.00$ \\
\hline Owah-Abe & $0.92 \pm 0.03$ & 0.01 & $0.90-0.96$ & $1.89 \pm 0.69$ & 0.34 & $1.40-2.90$ \\
\hline
\end{tabular}

Table 3: Levels of Heptachlor residues in T. mariae during the dry and wet seasons at three sites along the Ethiope River, sampled monthly from January - April (dry), May - August (wet). The means are based on monthly measurements.

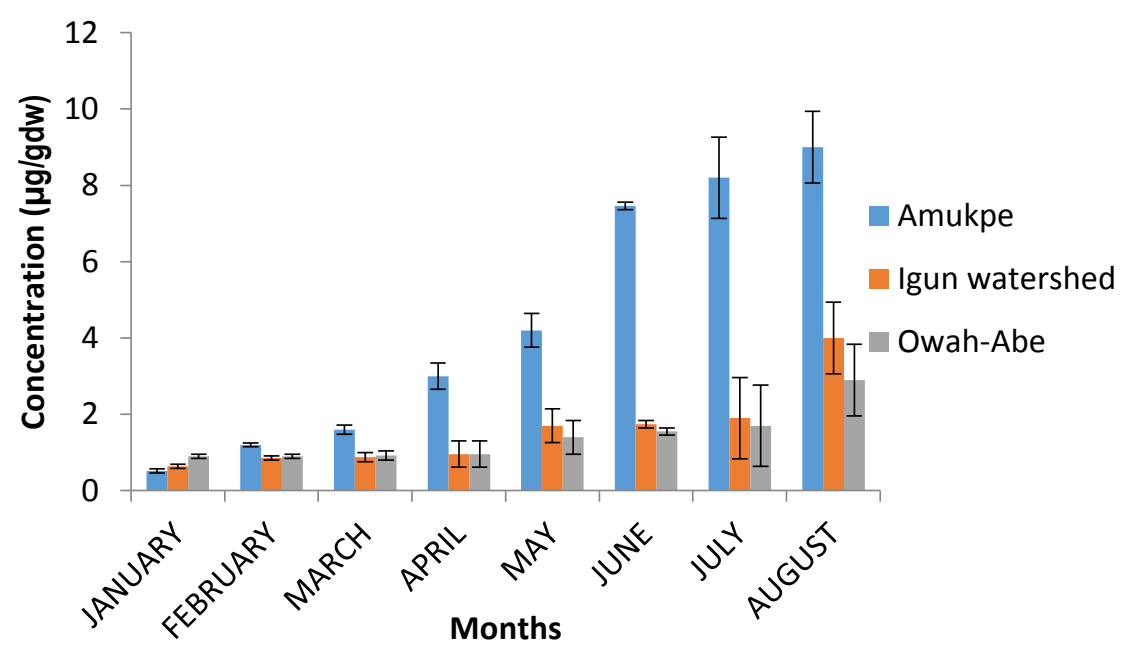

Figure 4: Heptachlor concentration in fish from the Ethiope River, Niger Delta, Nigeria. Data are presented as monthly concentrations \pm standard error.

\section{Discussion}

Ethiope River is surrounded by farm lands, and besides agriculture, other activities take place in the region around this River. Dumping of garbage and pouring of wastewater are regular activities by inhabitants, as the River at some point flows through some towns. These factors may very well lead to its contamination. Residues of the heptachlor were detected at varying concentrations in the three matrices examined in both seasons. Heptachlor sticks to sediment and soil and has the potential to travel distances in the wind from places where the concentration is high e.g. where is been used for crop treatments. In the environment, especially soil and water, heptachlor can be easily converted by bacteria into a dangerous, heptachlor epoxide. Heptachlor can be absorbed by the plants through their roots that are contact with the soil. During application, the pesticide can be easily deposited on plant leaves or penetrate plants from soil. 
In this investigation, the concentration of heptachlor in water was not as high as the concentration in sediment and fish. Nevertheless, water contaminated by heptachlor if ingested by human and animals, is readily converted to its most persistent toxic metabolites which are stored in fatty tissue, liver, kidney and muscle [11]. The concentration of heptachlor in T.mariae in this investigation was slightly higher than the concentration in sediment, and sediment higher than water. This could be attributed to the fact that residues of this pesticide accumulate in these matrices (sediment and fish) when they enter the river because they are less soluble in water [12]. This agrees with the work of Estok et al. [13] that sediment have large quantity of organic matter than the overlying water, which makes it a sink for persistent pollutants. Re-suspension of the pesticide in the sediment when the river's water is disturb either by natural course or anthropogenic activities may increase its bioavailability and accumulation in the fish as fishes acquire the pesticide through ingestion along with the water or dermal absorption [14]. This poses a problem for bigger fishes and man higher up in the tropic level when or if they consume such contaminated fishes as this may be hazardous to man's health, causing carcinogenic, respiratory, reproductive problems and brain damage especially in children [15]. A similar study also recorded higher concentrations of propoxur and endosulphan in fish than in sediment in Warri River also of the South Southern Nigeria, indicating possible bioaccumulation [16, 17]. Higher concentration of heptachlor in fish than in the sediment, which indicates a possible poor elimination in fish, similar report was given by [18] In this investigation, $0.52-8.20 \mu \mathrm{g} / \mathrm{g}$ residual level of heptachlor was recorded in $T$. mariae, a concentration higher than that observed by [19]) who recorded 0.027- $0.063 \mu \mathrm{g} / \mathrm{gdw}$ OCP in fish from a river in the South of Southern Nigeria.

Spatially, there was a significant variation in the heptachlor concentrations with the upstream station (Owah-Abe) recorded the least concentration of the pesticide. This could be related to the absence of agricultural activities in this station. But that pesticide was present, indicates the wide spread use of pesticide. Heptachlor concentration increases towards the downstream direction, with the station at Amukpe having the highest concentrations. Seasonally, the pesticide concentration during dry season was different from levels observed in the wet season. Dry season had higher concentration than the wet season for the surface water. This high concentration could be as a result of decreased in the volume of the river's water due to evaporation during the dry season. Similar reports were made by [20]. In contrast, higher concentration was recorded in the bottom sediment and T. mariae in the wet season than the dry season. This corroborates the conclusion of various workers that rainfall significantly increases pesticide mass loading to the aquatic habitat $[21,22,12]$.

The occurrence of the heptachlor in Ethiope River is consistent with the agricultural activities of the study farmers in the area. The pesticide residues were found across all stations and all the matrices in both seasons and in concentrations generally higher than the $0.3 \mu \mathrm{g} / \mathrm{g}$ permissible limits set by Nigeria National Environment Standards and Regulation Enforcement Agency (NESREA) for aquatic water bodies.

\section{Conclusion}

Heptachlor is very toxic to freshwater fish and aquatic organisms. Both heptachlor and its metabolite have been shown to bioaccumulate, bioconcentrate and biomagnifies along the tropic level. The pesticide has a stable structure, 
and can persist in the environment for a very long period. Its metabolite is not very susceptible to biodegradation, photolysis, oxidation, or hydrolysis in the environment. Heptachlor has between 6 months to 3.5 years in the soil, and traces have been found in soil 14 and 16 years after usage. The effects on organisms, especially non - target species is always fatal, therefore, caution should therefore be used to ensure that these products do not unnecessarily find its way into the water system. If the safety advice in the operation manual is adhere to the risk to humans and other animals will be minimal. Moreover, in developed world, the pesticide had been banned, yet in developing countries especially Africa continent and Asia, the pesticide still find its way into the market. Hence, the regulatory body should sensitize people on the implication of the continuous usage of banned substances and if possible exercise their power to curb the usage. Though, organisms can live freely in environment contaminated with heptachlor below the safety level for a very long period with no health effects. However, pesticides can easily biomagnified along the tropic level, and the risk to aquatic species become greater when repeated applications occur, resulting in continual exposure to peak concentrations.

\section{References}

1. Igbedioh SO. Effects of agricultural pesticides on humans, animals and higher plants in developing countries. Achieve of Environmental Health 15 (1991): 212-218.

2. Lanfranchi AL, Miglioranza ML, Menone KSB, et al. Striped weakfish (Cynoscion guatucupa): a biomonitor of organochlorine pesticides in estuarine and near-coastal zones. Marine Pollution Bulletin 43(2006): 74-80.

3. Adeyemi D, Ukpo G, Anyakora C, et al. Organochlorine pesticide residues in fish samples from Lagos Lagoon, Nigeria. America Journal of Environmental Science 4 (2008): 649-653.

4. OHS: Occupational Health Services, Inc. MSDS for Heptachlor. OHS, INc., Secaucus, NJ (1991).

5. ATSDR. Agency for Toxic Substances and Disease Registry. Toxicological Profile for Heptachlor/Heptachlor Epoxide. ATSDR/TP-88/16. ATSDR, US. Public Health Service, Washington, DC (1989).

6. ATSDR: Heptachlor and Heptachlor Epoxide - Fact Sheet (2007).

7. Guo Y, Meng XZ, Tang HL, et al. Tissue distribution of organochlorine pesticides in fish collected from the Pearl River delta, China: implications for fishery input source and bioaccumulation. Environmental Pollution 42 (2008): 150-156.

8. USEPA. Appendix 1 to Addendum. Environmental Fate and Ecological Risk Assessment of Endosulfan. Office of Prevention, Pesticides, and Toxic Substances (2007).

9. USEPA. Reregistration Eligibility Decision for Endosulfan. EPA 738-R-02-013. Pollution, Pesticides and Toxic Substances, United States Environmental Protection Agency (2002).

10. Afful S, Anim K, Serfor-Armah Y. Spectrum of organochlorine pesticide residues in fish samples from the Densu Basin. Research Journal of Environment and Earth Science 2 (2010): 133-138.

11. WHO. Guidelines for predicting dietary intake of pesticides residues. $2^{\text {nd }}$ Revised Edition, Document WHO/FSF/FOS/97.7. World Head Organization, Geneve (2003). 
12. Sara YP, Katharina O. Influence of Seasonal Changes toward Organochlorine Insecticide Residues in Fish, Water and Sediment from Upper Citarum Watershed Segment, Cisanti To Nanjung, West Java. Environmental Engineering Study Program, Bandung Institute of Technology (2009): 1-11.

13. Estok D, Freedman B, Boyle D. Effects of the herbicides 2,4-D, glyphosate, hexazinone, and triclopyr on the growth of three species of ectomycorrhizal fungi. Bull Environ Contamination and Toxicolology (1989): 835-839.

14. Aderinola O, Clarke E, Olarinmoye O, et al. Heavy Metals in Surface Water, Sediments, Fish and Periwinkles of Lagos Lagoon. Journal of Agriculture and Environmental Science 5 (2009): 609-617.

15. Eskenazi B, Asa B, Rosemary C. Exposures of Children to Organophosphate Pesticides and Their Potential Adverse Health Effects. University of California, Berkeley CA. Environmental Health Perspectives. Web of Science (1999):107-112.

16. Ezemonye LIN, Ikpesu TO, Isioma I. Distribution of propoxur in water,sediment and fish from Warri River, Nigeria. Turkish Journal of Biochemistry 2 ( 2009): 121-127.

17. Ezemonye LIN, Ikpesu TO, Isioma I. Distribution of endosulfan in water,sediment and fish from Warri River,Nigeria. Africa journal of Ecology 16 (2010): 238-254.

18. Wilfred OB. Pesticides in surface water. Distribution trends and governing factors. Pesticides in the Hydorologic System. S. Ann Arbor Press, Chelsea, M. I., USA. (1995)

19. Ize-Iyamu, OK, Asia IO, Egwakhide PA. Concentrations of residues from organochlorine pesticide in water and fish from some rivers in Edo State Nigeria. International Journal of Physical Science 2 (2007): 237241.

20. Ezemonye LIN, Ikpesu TO, Isioma I. Distribution of lindane in water, sediment and fish from Warri River, Nigeria. Archieve of Industrial Hygiene and Toxicology 7 (2008): 261-270.

21. Ezemoye LIN. Polychlorinated biphenyls (PCBs) levels and distribution in Ethiope and Benin Rivers of the Niger Delta, Surface water and sediment. International Journal of Environmental Studies. 65 (2005): 491504.

22. Uphadhi F, Wokoma OAF. Examination of some pesticide residues in surface water, sediment and fish tissue of Elechi Creek, Niger Delta Nigeria. Research Journal of Environmental and Earth Sciences 2 (2012): 939-944.

This article is an open access article distributed under the terms and conditions of the Creative Commons Attribution (CC-BY) license 4.0 